\title{
Digital Technologies in Ensuring the Protection of the Population and Territories of the Russian Federation from Natural and Man-Made Emergencies: Legal Aspect
}

\author{
Natalia Vedysheva ${ }^{1, *}$, Maria Mukhlynina $^{2}$, Olga Efimova $^{3}$, and Andrey Nikiforov ${ }^{4}$ \\ ${ }^{1}$ Kutafin Moscow State Law University, 125993 Moscow, Russia \\ ${ }^{2}$ Institute of State and Law of the Russian Academy of Sciences, 119019 Moscow, Russia \\ ${ }^{3}$ Moscow City Pedagogical University, 129226 Moscow, Russia \\ ${ }^{4}$ Moscow State Institute of International Relations (University) of the Ministry of Foreign Affairs of \\ the Russian Federation, 119454 Moscow, Russia
}

\begin{abstract}
The problem of sustainable management of digitalization of the environmental and technosphere security system at the legal and organizational levels both in the Russian Federation and in the world is now coming to the fore and requires immediate solutions. After analyzing strategic planning documents and other normative legal acts, the authors of the article attempt to consider current legal problems in the field under study in the aspect of digitalization, which ensures environmental and technosphere security of Russia, and implements the UN sustainable development goals in the environmental direction. The authors suggest that a successful economic policy aimed at achieving the UN sustainable development goals in the field of ensuring the safety of cities and human settlements is impossible without the introduction of science-based methodologies and tools for accounting for losses from disasters, improving modeling, assessment, monitoring of disaster risk, etc. In conclusion, a number of conclusions are drawn about the legal acts adopted in the Russian Federation and the organizational measures being implemented to help solve various problems related to the implementation of interdepartmental integrated systems of RSChS with the participation of the Ministry of digital development, communications and mass communications of Russia, etc.
\end{abstract}

\section{Introduction}

New global challenges of our time have forced us to change the outdated traditional model of the economy. Russia, like many other developed countries of the world, is currently undergoing a difficult process of reorientation to build a new model in accordance with the sustainable development Goals (sdgs) [1]. President Vladimir Putin has set an

*Corresponding author: veda120006@yandex.ru 
ambitious goal-Russia should become one of the five largest economies in the world in the next few years, with economic growth rates exceeding the world's [2]. One of the sustainable development goals (sdgs) adopted by the UN in 2015 is to ensure the openness, security, resilience and environmental sustainability of cities and human settlements (SDG 11). Currently, about half of the world's population (3.5 billion people). people) live in cities. By 2030, scientists predict that there will be about 5 billion such people.

The study of legal and organizational problems of system sustainable management of digital technologies in ensuring the protection of the population and territories of the Russian Federation from natural and man-made emergencies in our country is reflected in the works of Vedysheva N. O. [1], Mukhlynina M. M. [2], Abashidze A. Kh. and Chernykh I. A. [3], Zubarev S. M. [5], Zhavoronkova N. G. and Shpakovsky Yu. G. [6] and others.

\section{Methods}

The methodological basis of the research was made up of General scientific methods, so the analysis and synthesis were used to study existing theoretical and methodological approaches and provisions, as well as to conduct scientific research in the field of digital technologies in ensuring the protection of the population and territories of Russia from natural and man-made emergencies.

The information base of the article consists of normative legal acts, documents of state authorities and their officials, scientific works of scientists on the problems of improving digital technologies in the field under study $[4,7,8]$.

\section{Results and Discussion}

In the near future, urban growth will come at the expense of developing countries. Therefore, by 2030, the United Nations has set goals to expand the scope of open and environmentally sustainable urbanization and opportunities for sustainable human settlements planning; increase the number of cities that have adopted comprehensive strategies and plans aimed at, among other things, climate change mitigation and adaptation, as well as implementing measures for integrated disaster risk management at all levels in accordance with the Sendai framework for disaster risk reduction 2015-2030.

According to the above-mentioned program, in 2005-2015 alone, more than 700 thousand people died as a result of disasters, more than 1.4 million were injured, and about 23 million people were left homeless; the total economic damage exceeded 1.3 trillion. USD. By 2030, international instruments set goals to significantly reduce the number of deaths and victims of disasters; reduce direct economic losses from disasters relative to the world's gross product; and significantly reduce damage to critical infrastructure; improving the availability of early warning systems covering various types of threats and information on disaster risk, etc.

To ensure the safety of cities and localities, it is necessary to introduce science-based methodologies and tools for accounting for losses from disasters; improve modeling, assessment, and monitoring of disaster risk; exchange technologies and information using space satellites using geospatial data; and earth remote sensing data within the framework of international cooperation [3].

Russian national targets and indicators should contribute to achieving the results set out in the UN sdgs and the Sendai framework. In particular, the strategic planning documents provide for the development of a unified state system for emergency prevention and response, the introduction of hardware and software systems and technical means for monitoring, forecasting, informing the population about emergency situations (hereinafter referred to as emergencies), and threats of natural disasters. The provision of certain types 
of security has also been developed due to digitalization. Digital technologies are used for disaster management, infrastructure monitoring, search and rescue, and smart city development and urban planning. An example is the hardware and software complex "Safe city" [4], the main purpose of which was to increase the level of public safety, law and order and security of residential, public, administrative buildings, industrial and agricultural production facilities, public utilities, etc. by implementing a comprehensive information system on the basis of municipalities that provides forecasting, monitoring, prevention and elimination of natural, man-made, biological, social, and environmental threats, as well as monitoring the elimination of the consequences of emergencies and offenses. Disaster risk reduction is an investment that saves lives and property in the event of a disaster, and guarantees investors a reduction in the amount of expected damage caused by various accidents.

The main directions of the "Safe city" should include:

- formation of a communication platform for local self-government bodies in order to eliminate risks and ensure the safety of the population;

- development of functional and technical requirements for hardware and software that are focused on ensuring natural and man-made safety at the municipal level;

- ensuring information exchange between participants of all existing programs in the field of security through a single information space at the Federal, regional and municipal levels;

- building a situational analysis of the causes of destabilization and forecasting both existing and potential threats.

The main coordinator for the implementation and development of the Safe city agroindustrial complex in the regions is the Ministry of emergency situations of Russia, its coexecutors of measures for the construction and development of the complex at the Federal level are about 20 Ministries, services and agencies.

As rightly noted in the literature, the process of digitalization cannot but affect the sphere of public administration, which is understood as "... the process of introducing digital technologies into the activities of state bodies that allow for qualitative changes in the implementation of state functions and the provision of public services, and ensure effective interaction between citizens and the state" [5].

\section{Conclusions}

To solve the identified legal and organizational problems, it is necessary to support the introduction of digital technologies at the legislative level in the practical activities of state administration bodies at the Federal, sectoral and regional levels that ensure national security, it is necessary to "...determine the priority basic legal concepts and institutions necessary for digitalization of the sphere of environmental safety" [6].

Digitalization of the system for ensuring environmental and technosphere security involves the introduction of not only geoinformation technologies, but also artificial intelligence technologies, virtual reality, big data technologies, and others, which will require changes to the "emergency" legislation: the law on the protection of the population and territories from natural and man-made emergencies, the decree of the Government of the Russian Federation on the unified state system for preventing and eliminating emergencies, about approval of Rules of ensuring at the Federal level by the National center of management in crisis situations coordination of activity of bodies of daily management of the unified state system of the prevention and elimination of emergency situations and bodies of management of civil defense, the organization of information interaction of Federal Executive authorities, Executive authorities of subjects of the Russian Federation, local governments and organizations. 
It is necessary to improve the implementation of interdepartmental integrated systems of $\mathrm{RSChS}$ with the participation of the Ministry of digital development, communications and mass communications of Russia. In addition, it seems appropriate to give the recommendations on building a "Safe city" and the guidelines of the Ministry of emergency situations of the Russian Federation in this area (which are not even published) the status of a normative legal act that is mandatory, not Advisory in nature. As well as to consolidate the powers of the Executive authorities of the subjects and local self-government bodies in terms of creating and developing the agro-industrial complex "Safe city" [7].

In 2019, as part of the implementation of the Sendai framework for disaster risk reduction, work was actively continued to integrate NCCs into the international information network of crisis centers; assistance was provided in the activities of the International monitoring and coordination center (IOGO), issues of operational interaction and exchange of information with the Barents countries were worked out/The Euro-Arctic region, the UN who, and a translation of the Assessment map for cities on disaster resilience was prepared as part of the UN Global campaign to increase the resilience of 239 cities "My city is getting ready!" [8].

In accordance with the presidential decree of July 21, 2020 No. 474 "On the national development of the Russian Federation for the period till 2030" one of the goals identified digital transformation, which it is necessary to reach "digital maturity" of the main branches of economy, social sphere, health care; public administration; increasing the share of services in electronic form up to $95 \%$; increase investments in domestic decisions in the field of information technology in 4 times in comparison with indicators of 2019. This first "digital maturity" should be implemented in the system of EMERCOM and the Ministry of natural resources, to information about the state of the environment, monitoring of pollution, predicting the spread of forest fires over large distances, the analysis of risks and threats of natural and technogenic effects was available not only in the framework of the authority for the prevention and liquidation of emergency situations, and any citizen or representative of the business community through a digital platform.

\section{References}

1. M. Mukhlynina, N. Vedysheva, E3S Web of Conferences. Actual Problems of Ecology and Environmental Management: Cooperation for Sustainable Development and Environmental Safety, APEEM 2020, 05003 (2020)

2. M. Mukhlynina, E3S Web of Conferences. Actual Problems of Ecology and Environmental Management: Cooperation for Sustainable Development and Environmental Safety, APEEM 2020, 05008 (2020)

3. A. Kh. Abashidze, I. A. Chernykh, International Public and Private Law, 1, 12 (2020)

4. Order of the Government of the Russian Federation of 03.12.2014 № 2446-R "On approval of the Concept of construction and development of the hardware and software complex "Safe city", Sz RF, 50, 7220 (2014)

5. S. M. Zubarev, Actual Problems of Russian law, 6, 23 (2020)

6. N. G. Zhavoronkova, Yu. G. Shpakovsky, Lawyer, 4, 14 (2019)

7. The resolution of the Government of the Arkhangelsk region from 08.10.2013 №. 465PP "On approval of the state program of the Arkhangelsk region "Protection of population and territories of the Arkhangelsk region from emergency situations, ensuring fire safety and safety on water objects"

8. State Report on Protection of Population and Territories of the Russian Federation for 2019, https://www.mchs.gov.ru/ 